\title{
Algorithm for Calculating Flowrate of Fluid Energy Carrier for Flowmeter Based on Standard Long Radius Nozzle
}

\author{
Leonid Lesovoy ${ }^{*}$, Fedir Matiko, Iryna Maidanovych \\ Lviv Polytechnic National University, 12 Stepan Bandera St., Lviv, 79013, Ukraine
}

Received: April 04, 2021. Revised: November 12, 2021. Accepted: November 19, 2021.

() 2021 The Authors. Published by Lviv Polytechnic National University.

\begin{abstract}
New equation and algorithm are developed for non-iterative calculating flowrate of fluid energy carrier for pressure differential flowmeter based on long radius nozzle. This equation implicitly contains three build-in iterative cycles for calculating flowrate. According to the results of comparing the flowrate values obtained by developed non-iterative algorithm to the flowrate values by standard iterative algorithm, the authors found that the developed non-iterative algorithm ensures the accuracy of flowrate calculation specified by the requirements of DSTU GOST 8.586.5:2009. Therefore, the proposed equation and algorithm for calculating flowrate can be used for flowmeters based on standard long radius nozzle for both technological and commercial metering flowrate of fluid energy carriers. Application of the developed algorithm makes it possible to increase the speed of calculating flowrate of fluid energy carriers by means of microprocessor controllers.
\end{abstract}

Keywords: flowrate; pressure differential method; primary device; long radius nozzle; algorithm.

\section{Introduction}

Pressure differential method is widely used for metering flowrate of fluid energy carriers. The basic principles of this method and the requirements for its application are presented in many sources, particularly, in the international standards ISO 5167-1,2,3,4: 2003 [1] - [4] and in the national standards DSTU GOST 8.586.1,2,3,4,52009 [5] - [9], which are implemented in Ukraine.

Pressure differential method is a complex indirect method of measuring flowrate and quantity of fluid energy carrier, which provides for measuring differential pressure across a primary device, absolute pressure and temperature of fluid and calculating flowrate and quantity of fluid energy carrier using these measured values. Since the coefficients of the flowrate equation depend on fluid flowrate, the process of it calculating is iterative. In addition to iterative calculating the fluid parameters and the coefficients of flowrate equation, algorithm for calculating the fluid flowrate should also provide for checking in a certain sequence conditions and limitations of pressure differential method. Following characteristics should be checked:

- range of permissible values of fluid energy carrier parameters;

- characteristics of primary device;

- characteristics of measuring pipeline, its rectilinear sections and equipment;

- eccentricity;

- protrusions and difference in diameters of adjacent sections of measuring pipeline.

\footnotetext{
* Corresponding author. Email address: techinfoflow@yahoo.co.uk
}

This paper should be cited as: L. Lesovoy, F. Matiko, I. Maidanovych. Algorithm for calculating flowrate of fluid energy carrier for flowmeter based on standard long radius nozzle. Energy Engineering and Control Systems, 2021, Vol. 7, No. 2, pp. 117 - 125. https://doi.org/10.23939/jeecs2021.02.117 
By meeting all these requirements, one obtains a complex algorithm for calculating flowrate and quantity of fluid, which should be implemented in microprocessor flowrate calculators. The flowrate calculator implements this algorithm in real time within the limited duration of the program cycle and the limited computing power of the calculator. Therefore, it is an urgent task to simplify the algorithm for calculating flowrate and eliminate the iterative process of calculating the flowrate, which takes considerable part of the computer program cycle.

\section{Analysis of publications and research}

When designing a new pressure differential flowmeter for fluid energy carrier based on standard primary device, it is necessary to solve the following problems:

- to do a direct calculation of pressure differential flowmeter, during which the diameter of hole or throat of a standard primary device for a given flowrate of fluid energy carrier should be determined;

- to make a standard primary device and to check its characteristics for compliance with the requirements of the standards;

- to do a reverse calculation of pressure differential flowmeter, which consists in determining the flowrate of fluid energy carrier for specified characteristics of standard primary device and measuring pipeline.

Pressure differential flowmeters for flowrate and quantity of fluid energy carriers use the following standard primary devices: orifice plates [2], [6], [10]; ISA 1932 nozzles, long radius nozzles, Venturi nozzles [3], [7], [10]; Venturi pipes of different types [4], [8], [10]. The use of a long radius nozzle has some advantages for measuring the flowrate of fluid energy carrier compared to the orifice plate:

- it has stable characteristics during long operation time;

- it has less pressure loss than orifice plate;

- it may have diameter ratio of throat up to 0.8 .

Therefore, it is often used to measure flowrate of dry saturated steam.

Discharge coefficient of long radius nozzle depends on Reynolds number and, therefore, on flowrate of fluid energy carrier. So, nozzle flowrate equation is an implicit equation and calculation of flowrate of fluid energy carrier through long radius nozzle is carried out iteratively. According to ISO 5167-1: 2003 [1], iterations are recommended to be performed by the value of Reynolds number or by the value of mass flowrate of fluid energy carrier [5], [10]. This increases the amount of memory and the time required for calculating the mass flowrate and the quantity of fluid energy carrier, and thus increases the requirements to microprocessors or microcontrollers used in flowrate calculators of fluid energy carrier.

It should be noted that simplified algorithms could be used to calculate the fluid flowrate, but these algorithms would increase the relative error of calculation of fluid flowrate. The additional error caused by simplified algorithm may be systematic, and therefore can create an additional imbalance in the accounting of energy carriers in distribution and transmission systems.

To check the algorithms for calculating the values of fluid flowrate, it is necessary to have tables of control points (tests), by which fluid flowrate and relative extended uncertainty of flowrate for the specified ranges of pressure and temperature of fluid are determined. Such tables can be obtained using CAD "RASKHOD-RU" [11], [12].

Based on mathematical model of pressure differential flowmeter, a technique for calculating the flowrate of fluid energy carrier is implemented in CAD "Raskhod-RU" [11], [12]. It is implemented in a form of optimized algorithm with cyclic calculation. The body of the cycle calculates the coefficients of flowrate equation, which depends on fluid flowrate, in particular discharge coefficient $\mathrm{C}$, Reynolds number Re, fluid parameters, as well as a number of other coefficients of flowrate equation that do not depend on fluid flowrate. At the end of the cycle body the relative deviation $\delta_{q_{m}}$ of the current value of the mass flowrate $q_{m i}$ of fluid energy carrier from its previous value $q_{m i-1}$ is calculated. Exit from the cycle is carried out when the relative deviation of flowrate becomes less than the allowable calculation error which equals $0.001 \%$ according to the standards [9] and [15].

\section{Goal of the paper}

The goal of this paper is to develop a non-iterative algorithm for calculating mass flowrate $q_{m}$ of fluid energy carrier in order to reduce the required controller memory and to increase the speed of calculating the flowrate and the quantity of fluid energy carrier by means of microprocessor calculators of fluids. 


\section{Presentation and discussion of the research results}

Mass flowrate $q_{m}$ is determined according to equations of the standards [1], [5], [9] and [11]:

- for liquid energy carrier

$$
q_{m}=\frac{\pi}{4} d^{2} E C \sqrt{2 \Delta p \rho}
$$

- for gaseous energy carrier

$$
q_{m}=\frac{\pi}{4} d^{2} E C \varepsilon \sqrt{2 \Delta p \rho}
$$

where $d$ is the diameter of the long radius nozzle throat at temperature of energy carrier; $E$ is the velocity of approach factor; $\Delta p$ is differential pressure across long radius nozzle; $\rho$ is the density of fluid energy carrier at temperature and static pressure of fluid energy carrier; $\varepsilon$ is the expansibility factor of energy carrier.

Velocity of approach factor $E$ depends on diameter ratio $\beta$ of long radius nozzle. It is calculated by the equation

$$
E=\frac{1}{\sqrt{1-\beta^{4}}} .
$$

Diameter ratio of primary device installed in a pipeline is the ratio of the diameter throat of long radius nozzle to the internal diameter $D$ of measuring pipe upstream the primary device:

$$
\beta=\frac{d}{D}
$$

Diameter $d$ of the long radius nozzle throat at a temperature of fluid energy carrier is determined by formula

$$
d=d_{20} K_{\mathrm{Cy}}
$$

where $d_{20}$ is the diameter of throat of long radius nozzle at fluid temperature $20^{\circ} \mathrm{C} ; K_{\mathrm{Cy}}$ is the coefficient that takes into account the change in the diameter of the throat of long radius nozzle caused by deviations of fluid temperature from $20^{\circ} \mathrm{C}$.

Internal diameter $D$ of the measuring pipe upstream the primary device at a temperature of fluid energy carrier depends on the internal diameter $D_{20}$ of the measuring pipe upstream the primary device at a temperature of energy carrier $20^{\circ} \mathrm{C}$. It is calculated by following equation

$$
D=D_{20} K_{\mathrm{T}},
$$

where $K_{\mathrm{T}}$ is the coefficient that takes into account the change in the internal diameter $D$ of the measuring pipe upstream the primary device caused by deviations of fluid temperature from $20^{\circ} \mathrm{C}$.

Discharge coefficient $C$ of a long radius nozzle with small and large diameters ratio is determined according to [3], [7], [10]:

$$
C=0.9965-0.00653 \sqrt{\frac{10^{6} \beta}{\operatorname{Re}}},
$$

where Re is Reynolds number, which is the ratio of the inertia force to the fluid viscosity force and it is determined by the equation 


$$
\operatorname{Re}=\frac{\bar{w} D \rho}{\mu},
$$

where $\bar{w}$ is the longitudinal component of the average local velocity of fluid energy carrier in the measuring pipeline; $\mu$ is the dynamic viscosity of the fluid energy carrier in the measuring pipeline.

Expansibility factor $\varepsilon$ of fluid energy carrier is calculated according to [3], [7], [10]:

$$
\varepsilon=\left\{\begin{array}{l}
\sqrt{\left(\frac{\kappa \tau^{\frac{2}{\kappa}}}{\kappa}\right)\left(\frac{1-\beta^{4}}{1-\beta^{4} \tau^{\frac{2}{\kappa}}}\right)\left(\frac{1-\tau^{\frac{\kappa-1}{\kappa}}}{1-\kappa}\right)} \text { for gaseous energy carrier }, \\
1 \quad \text { for liquid energy carrier }
\end{array}\right.
$$

where the values of $\tau$ are calculated by formula

$$
\tau=1-\frac{\Delta p}{p}
$$

Equation (9) is applied for the ratio $\frac{\Delta p}{p} \leq 0.25$.

Let's write the equation (1) or (2) for determining the mass flowrate $q_{m}$ of fluid energy carrier using average fluid velocity $\bar{w}$ the in the following form

$$
q_{m}=\frac{\pi D^{2}}{4} \rho \bar{w}
$$

and determine the average local velocity $\bar{w}$ of fluid the in the measuring pipeline as

$$
\bar{w}=\frac{4 q_{m}}{\pi D^{2} \rho} .
$$

Substituting the average local velocity $\bar{w}$ of fluid in the measuring pipeline into equation (8), we obtain the formula for calculating Reynolds number in terms of mass flowrate $q_{m}$ of fluid

$$
\operatorname{Re}=\frac{4 q_{m}}{\pi D \mu}
$$

Taking into account formula (7), we obtain an equation for determining mass flowrate $q_{m}$ of fluid energy carrier in the form

$$
q_{m}=\frac{\pi}{4} d^{2} E \varepsilon\left(0.9965-0.00653 \sqrt{\frac{10^{6} \beta}{\operatorname{Re}}}\right) \sqrt{2 \Delta p \rho}
$$

Taking into account formula for determining the Reynolds number (13), we obtain the equation for determining mass flowrate $q_{m}$ of fluid energy carrier as a function of mass flowrate $q_{m}=\mathrm{f}\left(q_{m}\right)$. This equation can be solved with respect to $q_{m}$ using iterative methods for solving the equation. These methods increase the time that processor or microprocessor controller spends to solve such iterative problem. 
The authors developed an equation for non-iterative calculating mass flowrate of fluid measured by using long radius nozzle. The initial form of the equation is obtained by substituting expression (13) in equation (14):

$$
q_{m}=0.9965 \frac{\pi}{4} d^{2} E \varepsilon \sqrt{2 \Delta p \rho}\left(1-\frac{0.00653}{0.9965} \sqrt{\frac{10^{6} \pi d \mu}{4 q_{m}}}\right)
$$

The equation (15) is presented in the form

$$
q_{m}=A\left(1+\frac{B}{\sqrt{q_{m}}}\right)
$$

where

$$
\begin{gathered}
A=0.9965 \frac{\pi}{4} d^{2} E \varepsilon \sqrt{2 \Delta p \rho} \\
B=-\frac{0.00653}{1.993} \sqrt{10^{6} \pi d \mu}
\end{gathered}
$$

Substituting the equation for determining the mass flowrate $q_{m}$ of fluid energy carrier in equation (16), we obtain the following formula

$$
q_{m}=A\left(1+\frac{B_{0}}{\sqrt{1+\frac{B}{\sqrt{q_{m}}}}}\right),
$$

where

$$
B_{0}=\frac{B}{\sqrt{A}}
$$

In the third iteration step we've written the equation for determining the mass flowrate $q_{m}$ of the fluid energy carrier and substituted formula (20) into it. Finally, we've obtained the equation for calculating the mass flowrate of fluid energy carrier in the form

$$
q_{m}=A\left(1+\frac{B_{0}}{1+\frac{B_{0}}{\sqrt{1+\frac{B_{0}}{\sqrt{1+\frac{2 B}{\sqrt{\pi d \mu} \sqrt{\operatorname{Re}_{a}}}}}}}}\right),
$$


where $\operatorname{Re}_{a}$ is the average value of the Reynolds number, which should be calculated by the equation

$$
\operatorname{Re}_{a}=10^{0.5\left[\lg \left(\operatorname{Re}_{\min }\right)+\lg \left(\operatorname{Re}_{\max }\right)\right]},
$$

$\mathrm{Re}_{\min }, \mathrm{Re}_{\max }$ are the minimum and the maximum allowable values of Reynolds number, which for the long radius nozzle are $\operatorname{Re}_{\text {min }}=10^{4}$ and $\operatorname{Re}_{\max }=10^{7}$ [7].

According to the equation (22), the average value of Reynolds number for a long radius nozzle is $\operatorname{Re}_{a}=316228$.

Replacing the equation

$$
B_{1}=\frac{2 B}{\sqrt{\pi D \mu}{\sqrt{\operatorname{Re}_{a}}}_{a}}=-0.01165295 \sqrt{\beta} ;
$$

and substituting it in equation (22), we obtain the equation for determining the mass flowrate of the fluid energy carrier

$$
q_{m}=A\left(1+\frac{B_{0}}{\sqrt{1+\frac{B_{0}}{\sqrt{1+\frac{B_{0}}{\sqrt{1+B_{1}}}}}}}\right) .
$$

It is obvious from the presented procedure for obtaining equation (24) that this equation implicitly contains three build-in iterative cycles for calculating flowrate. As the authors will show below, these build-in iterative cycles are sufficient to achieve the accuracy of fluid mass flowrate calculation specified in standards [9] and [10]. Figure 1 shows a flowchart of algorithm for calculating fluid mass flowrate, developed by the authors on the basis of equation (24).

We can see from Figure 1 that developed algorithm for calculating mass flowrate provides sequential noniterative process for implementing the equation (24). A disadvantage of equation (24) and respectively of proposed algorithm is that it can be used to calculate the fluid mass flowrate through only primary device of a certain type - a standard long radius nozzle.

The developed algorithm was used to calculate the mass flowrate for two sets of fluid parameters and flowmeter characteristics (see Table 1).

Table 2 presents the results of calculating mass flowrate of the fluid energy carrier (natural gas), which is determined using the iterative method and the non-iterative algorithm developed on the basis of equations (17), (18), (20), (23) and (24). The relative deviation of the values of the mass flowrate of the fluid energy carrier obtained during the iterative process (see Table 2), is calculated by the formula

$$
\delta_{q_{m}}=100\left(\frac{q_{m i-1}-q_{m i}}{q_{m i}}\right),
$$

where $q_{m i-1}$ and $q_{m i}$ are the mass flowrate of fluid at the previous time and at the current time, respectively. 

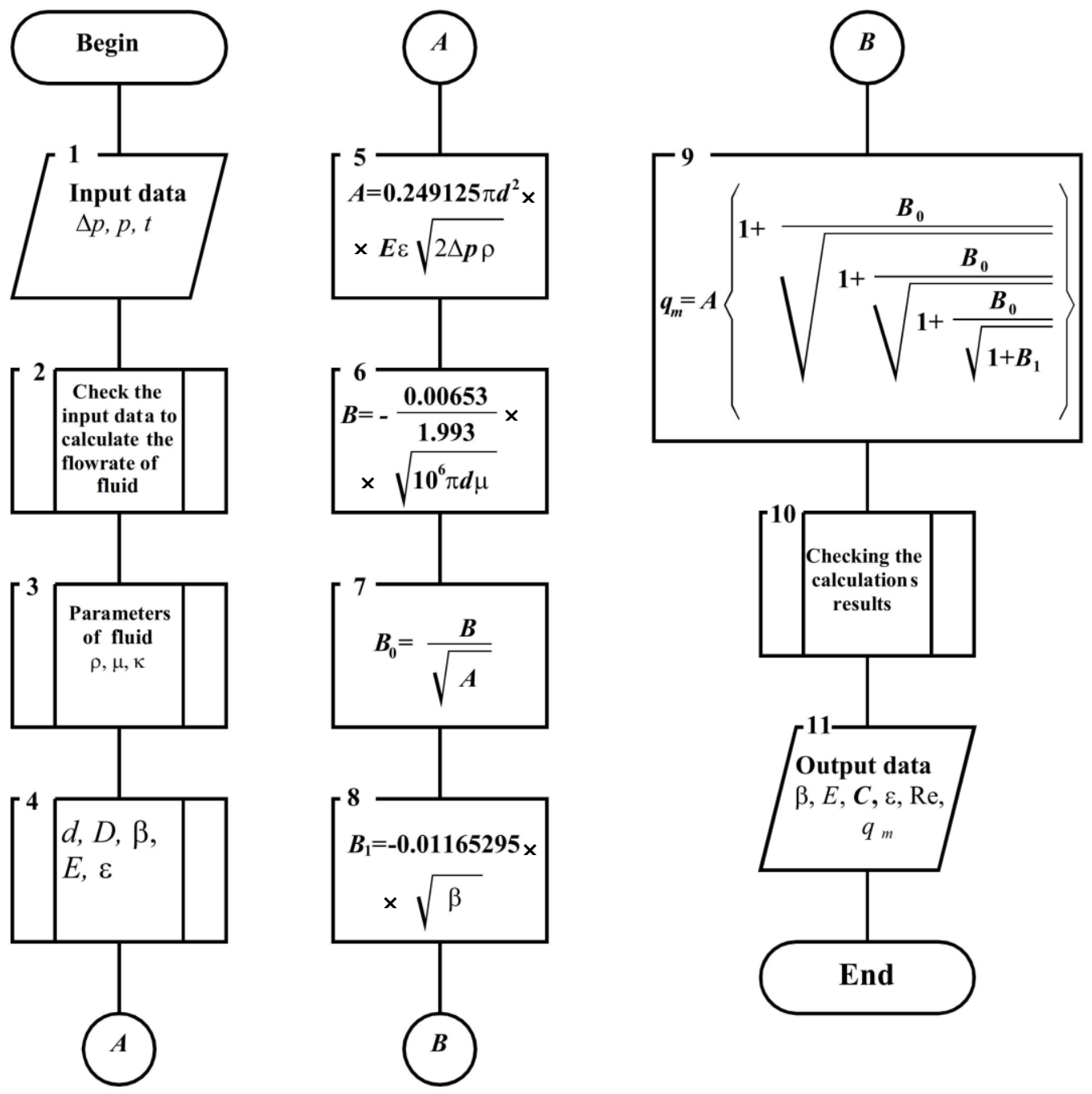

Fig.1. Flowchart of a non-iterative algorithm for determining the mass flowrate of fluid energy carrier.

Table 1. Input data for calculating the mass flowrate of fluid energy carrier

\begin{tabular}{|c|c|c|}
\hline \multirow{2}{*}{ Fluid parameter or flowmeter characteristic } & \multicolumn{2}{|c|}{ Parameter or characteristic value } \\
\hline & Flowmeter 1 & Flowmeter 2 \\
\hline Differential pressure across long radius nozzle, $\mathrm{Pa}$ & 240 & 12000 \\
\hline Absolute pressure of fluid energy carrier, $\mathrm{Pa}$ & 250000 & 250000 \\
\hline Temperature of fluid energy carrier, ${ }^{\circ} \mathrm{C}$ & 10 & 10 \\
\hline Density of fluid energy carrier at standard conditions, $\mathrm{kg} / \mathrm{m}^{3}$ & 0.68 & 0.7 \\
\hline Molar fraction of carbon dioxide in natural gas, $\%$ & 0 & 0.2 \\
\hline Molar fraction of nitrogen in natural gas, $\%$ & 0 & 0.9 \\
\hline Density of fluid energy carrier at working conditions, $\mathrm{kg} / \mathrm{m}^{3}$ & 1.79445 & 1.79455 \\
\hline Isentropic exponent of fluid energy carrier, 1 & 1.30375 & 1.30175 \\
\hline Dynamic viscosity of fluid energy carrier, $\mathrm{Pa} \cdot \mathrm{s}$ & $1.061910^{-5}$ & $1.061910^{-5}$ \\
\hline Throat diameter of long radius nozzle at fluid temperature $20{ }^{\circ} \mathrm{C}, \mathrm{mm}$ & 14.77 & 480 \\
\hline Material of the long radius nozzle & $12 \mathrm{X} 18 \mathrm{H} 10 \mathrm{~T}$ & $12 \mathrm{X} 18 \mathrm{H} 10 \mathrm{~T}$ \\
\hline $\begin{array}{l}\text { Internal diameter of the measuring pipe upstream the primary device at } \\
\text { fluid temperature } 20^{\circ} \mathrm{C}, \mathrm{mm}\end{array}$ & 50.2 & 600 \\
\hline Material of the measuring pipe & St. 20 & St. 20 \\
\hline $\begin{array}{l}\text { Roughness of the inner surface of the measuring pipe is selected from } \\
\text { the table DSTU GOST 8.586.1:2009 [10] }\end{array}$ & \multicolumn{2}{|c|}{ All drawn steel and cold drawn (new) } \\
\hline
\end{tabular}


Table 2. Comparison of the results of calculating the mass flowrate for fluid energy carrier obtained by using iterative algorithm (columns 1-3) and new non-iterative algorithm (columns 4-6)

\begin{tabular}{|c|c|c|c|c|c|}
\hline \multirow{2}{*}{ Parameter } & \multicolumn{2}{|c|}{ Value } & \multirow{2}{*}{ Parameter } & \multicolumn{2}{|c|}{ Value } \\
\hline & Flowmeter 1 & Flowmeter 2 & & Flowmeter 1 & Flowmeter 2 \\
\hline 1 & 2 & 3 & 4 & 5 & 6 \\
\hline $\begin{array}{l}\text { Diameter ratio } \beta \text { of long radius } \\
\text { nozzle, (4) }\end{array}$ & 0.294208 & 0.799959 & $\begin{array}{l}\text { Diameter ratio } \beta \text { of long radius } \\
\text { nozzle, (4) }\end{array}$ & 0.294208 & 0.799959 \\
\hline Velocity of approach factor $E$, (3) & 1.00377 & 1.30136 & Velocity of approach factor $E$, (3) & 1.00377 & 1.30136 \\
\hline $\begin{array}{l}\text { Expansibility factor of gaseous } \\
\text { energy carrier } \varepsilon,(9)\end{array}$ & 0.999441 & 0.948368 & $\begin{array}{l}\text { Expansibility factor of gaseous } \\
\text { energy carrier } \varepsilon,(9)\end{array}$ & 0.999441 & 0.948368 \\
\hline Reynolds number, $\mathrm{Re}_{0}$ & $10^{6}$ & $10^{6}$ & Coefficient $A,(18), \mathrm{kg} / \mathrm{s}$ & 0.004955281 & 46.17047 \\
\hline $\begin{array}{l}\text { Discharge coefficient } C_{0} \text { of long } \\
\text { radius nozzle, (7) }\end{array}$ & 0.992958 & 0.99065954 & Coefficient $B,(19),(\mathrm{kg} / \mathrm{s})^{0.5}$ & -0.00230179 & -0.0131102 \\
\hline $\begin{array}{l}\text { Mass flowrate of fluid energy } \\
\text { carrier } q_{m 0},(2), \mathrm{kg} / \mathrm{s}\end{array}$ & 0.00493521 & 45.89986184 & Coefficient $B_{0},(21)$ & -0.032706934 & -0.001929415 \\
\hline Reynolds number, $\operatorname{Re}_{1},(13)$ & 11767.9 & 9173504 & Coefficient $B_{1},(25)$ & -0.006320671 & -0.01042245 \\
\hline $\begin{array}{l}\text { Discharge coefficient } C_{1} \text { of long } \\
\text { radius nozzle, (5) }\end{array}$ & 0.963849 & 0.994572 & $\begin{array}{l}\text { Mass flowrate of fluid energy } \\
\text { carrier } q_{m 0},(24), \mathrm{kg} / \mathrm{s}\end{array}$ & 0.00478806 & 46.0813 \\
\hline $\begin{array}{l}\text { Mass flowrate of fluid energy } \\
\text { carrier } q_{m 1},(2), \mathrm{kg} / \mathrm{s}\end{array}$ & 0.00479053 & 46.0811 & - & - & - \\
\hline $\begin{array}{l}\text { Relative error of calculation result } \\
\text { of mass flowrate of fluid energy } \\
\text { carrier } \delta_{q_{m}},(25), \%\end{array}$ & 3.020 & -0.393 & - & - & - \\
\hline Reynolds number, $\mathrm{Re}_{2}$, (13) & 11422.95 & 9209731 & - & - & - \\
\hline $\begin{array}{l}\text { Discharge coefficient } C_{2} \text { of long } \\
\text { radius nozzle, }(5)\end{array}$ & 0.963360 & 0.994575 & - & - & - \\
\hline $\begin{array}{l}\text { Mass flowrate of fluid energy } \\
\text { carrier } q_{m 2},(2), \mathrm{kg} / \mathrm{s}\end{array}$ & 0.00478810 & 46.0813 & - & - & - \\
\hline $\begin{array}{l}\text { Relative error of calculation result } \\
\text { of mass flowrate of fluid energy } \\
\text { carrier } \delta_{q_{m}},(25), \%\end{array}$ & 0.050 & $0.000<0.001$ & - & - & - \\
\hline Reynolds number, $\operatorname{Re}_{3},(13)$ & 11417.16 & - & - & - & - \\
\hline $\begin{array}{l}\text { Discharge coefficient } C_{3} \text { of the long } \\
\text { radius nozzle, }(5)\end{array}$ & 0.963352 & - & - & - & - \\
\hline $\begin{array}{l}\text { Mass flowrate of fluid energy } \\
\text { carrier } q_{m 3},(2), \mathrm{kg} / \mathrm{s}\end{array}$ & 0.00478806 & - & - & - & - \\
\hline $\begin{array}{l}\text { Relative error of calculation result } \\
\text { of mass flowrate of fluid energy } \\
\text { carrier } \delta_{q_{m}},(25), \%\end{array}$ & $0.001 \leq 0.001$ & - & - & - & - \\
\hline
\end{tabular}

We can see from Table 2 that four iterations of iterative algorithm for calculating flowrate make it possible to meet the requirements to the accuracy of flowrate calculation specified by standards [9] and [10]. Applying the equation (24) and non-iterative algorithm, one can achieve the same accuracy of calculating flowrate, while reducing the calculation time.

\section{Conclusion}

A simplified equation (24) for calculating the fluid flowrate measured by using a standard long radius nozzle is proposed in the paper. The equation makes it possible to calculate the flowrate of gases and liquids. Based on equation (24), a non-iterative algorithm for calculating the fluid flowrate is developed, which is proposed for implementation into pressure differential calculators of fluids flowrate and quantity.

According to the results of comparing the flowrate values obtained by developed non-iterative algorithm to the flowrate values by standard iterative algorithm, the authors found that the developed non-iterative algorithm ensures the accuracy of flowrate calculation specified by the requirements of DSTU GOST 8.586.5:2009. Therefore, the 
proposed equation and algorithm for calculating flowrate can be used for flowmeters based on standard long radius nozzle for both technological and commercial metering flowrate of fluid energy carriers. Application of the developed algorithm makes it possible to increase the speed of calculating flowrate of fluid energy carriers by means of microprocessor controllers.

\title{
References
}

[1] ISO 5167-1:2003. Measurement of Fluid Flow by Means of Pressure Differential Devices Inserted in Circular Cross-Section Conduits Running Full-Part 1: General Principles and Requirements.

[2] ISO 5167-2:2003. Measurement of Fluid Flow by Means of Pressure Differential Devices Inserted in Circular Cross-Section Conduits Running Full-Part 2: Orifice Plates.

[3] ISO 5167-3:2003. Measurement of Fluid Flow by Means of Pressure Differential Devices Inserted in Circular Cross-Section Conduits Running Full-Part 3: Nozzles and Venturi Nozzles.

[4] ISO 5167-4:2003. Measurement of Fluid Flow by Means of Pressure Differential Devices Inserted in Circular Cross-Section Conduits Running Full-Part 4: Venturi Tubes.

[5] DSTU GOST 8.586.1: 2009 (ISO 5167-1:2003). State system for ensuring the uniformity of measurements. Measurements of liquid and gas flow rate and quantity by means of orifice instruments. Part 1. Principle method of the of measurements general requirements. (Ukrainian)

[6] DSTU GOST 8.586.2: 2009 (ISO 5167-2:2003). State system for ensuring the uniformity of measurements. Measurements of liquid and gas flow rate and quantity by means of orifice instruments. Part 2. Orifice plates. Technical requirements. (Ukrainian)

[7] DSTU GOST 8.586.3: 2009 (ISO 5167-3:2003). State system for ensuring the uniformity of measurements. Measurements of liquid and gas flow rate and quantity by means of orifice instruments Part 3. Nozzles and Venturi nozzles. Technical requirements (Ukrainian)

[8] DSTU GOST 8.586.4: 2009 (ISO 5167-4:2003). State system for ensuring the uniformity of measurements. Measurements of liquid and gas flow rate and quantity by means of orifice instruments. Part 4. Venturi tubes. Technical requirements (Ukrainian)

[9] DSTU GOST 8.586.5: 2009. State system for ensuring the uniformity of measurements. Measurements of liquid and gas flow rate and quantity by means of orifice instruments. Part 5. Measurement procedure. (Ukrainian)

[10] Pistun, Y. and Lesovoy, L. (2006) Normalization of Pressure Differential Flow Meters. Publishing House of Institute of Energy Audit and Energy Carrier Accounting, Lviv, 576. (Ukrainian)

[11] Pistun, Y., Lesovoy, L., Matiko, F., Markovskyi, D. and Lesovoy, R. (2007) "RASKHOD-RU” CAD computer program. User manual. Publishing House of Institute of Energy Audit and Energy Carrier Accounting (www.ieoe.com.ua), Lviv, 128. (Ukrainian)

[12] Fedoryshyn, R.; Lesovoi, L. \& Pistun, Y. (2010). "Raskhod-RU” CAD system for computer aided calculation and design of flowmeters for fluid energy carriers (2010). 0557-0558, Annals of DAAAM for 2010 \& Proceedings of the 21st International DAAAM Symposium, ISBN 978-3-901509-68-1, ISSN 1726-9679, pp. 347, Editor B. Katalinic, Published by DAAAM International, Vienna, Austria 2010.

\section{Алгоритм розрахунку витрати плинного енергоносія для витратоміра на основі стандартного еліпсного сопла}

\author{
Леонід Лесовой, Федір Матіко, Ірина Майданович \\ Національний університет «Львівська політехніка», вул. Степана Бандери, 12, Львів, 79013, Украӥна
}

\section{Анотація}

Розроблено нове рівняння та алгоритм для безітераційного розрахунку витрати плинного енергоносія для витратоміра змінного перепаду тиску на основі еліпсного сопла. Це рівняння містить у неявному вигляді три вкладені ітераційні цикли обчислення витрати. За результатами порівняння значень витрати, отриманих за розробленим безітераційним алгоритмом із значеннями витрати, отриманими за стандартизованим ітераційним алгоритмом, авторами встановлено, що розроблений безітераційний алгоритм забезпечує точність обчислення витрати визначену вимогами стандарту ДСТУ ГОСТ 8.586.5:2009. Отже, запропоноване рівняння та алгоритм обчислення витрати можуть бути застосовані у витратомірах на основі стандартного еліпсного сопла як для технологічного так і комерційного обліку плинних енергоносіїв. Застосування розробленого алгоритму дає можливість підвищити швидкість розрахунку витрати енергоносія за допомогою мікропроцесорних контролерів.

Ключові слова: витрата; метод змінного перепаду тиску; звужувальний пристрій; еліпсне сопло; алгоритм. 